\title{
Designing Brand Culture Based on the Advertising's New Medium of Human Experience: Integrating the Application in Lifestyle Retailing Strategy
}

\author{
Stephen T.F. Poon
}

Taylor's University, Malaysia

\begin{abstract}
Human experiences play a significant part in engaging consumers with brands. Carefully orchestrated brand messages constructed on various emotional associations involves more than managing costs and logistical considerations efficiently. Effective integrated marketing communication and advertising campaigns, public relations and media strategies see the opportunity to tap into human experiences and emotions that are as widely diverse in attitudes, patterns and behaviours as they are bundled, when consumers are aggregated into communities of mutual interests in terms of habits, lifestyles, purchasing decisions and motivations. This paper critically examines the subject of human experiences in the context of lifestyle retailing concepts, and examines integrated marketing and branding approaches based on the four spheres of experiences in the cultural realm, namely public, social, tribal and psychological. Where the totality of our living experiences help us relate, add value to, and express preferences for, certain consumer goods, it is argued that marketing today must develop and sustain a business case for creative application of all these experiences in strategic decision making. The case study of international furniture retailer IKEA is presented to understand its integration of the four spheres of experiences into functional marketing strategies. Findings of this research shows the company's use of cultural realm of human experiences to articulate a compelling brand image associated with credibility, authenticity and sustainability. The insights gained from researching human experiences informs the marketing industry and brand communicators that cultural attitudes such as loyalty and group affiliation directly affects the level of consumer engagement with brands, enhancing salience, increasing expectations, emotional satisfaction, cultural relevance and valuable experiences.
\end{abstract}

Keywords: human experience, cultural marketing, design, retail

\section{INTRODUCTION}

Branding is no longer a generic term that it once was. The enormous growth of businesses seeking strong brand communication to make goods more meaningful in the marketplace economy has made brands the very lifeblood of organisations. Successful brands today spend time investing in researching, defining and developing key messages that attract and build relationships, adding consumer value and satisfaction. Hence, the rationale for the integration of branding and marketing strategies becomes clear. This paper discusses the use of the 'human experiences' model for consumer engagement by Jeffrey Rayport (2013). The aim of the study is to understand how far human experiences shape the way companies leverage knowledge of the consumers' point of view in their branding strategies, and how this knowledge is integrated into cultural retailing strategies to build global brand cultures.

\section{LITERATURE REVIEW}

A brand is the idea or image of products or services that consumers associate and identify with, which differentiates goods and businesses through its name, term, slogan, symbol or design (Kotler, Wong, Saunders and Armstrong, 2005: 549). Branding activities revolve around determining, shaping and selling that idea or image to consumers (existing and potential) in order to increase recognition and to position goods or services distinctly from competitors (Kotler et al, 2005: 255).

Scholarly literature on advertising, branding, marketing and product innovation abounds. Improving on classical marketing theories, researchers place increasing emphasis on 'relationships': for instance, David Aaker (2011:160) suggests the importance of the friendship context, stating "trust, dependabili ty, understanding and caring" to be definitive in cementing customer loyalty over a long period. Discussions also revolve around OPR (Organisation-Public Relationship), as researchers sense a shift 
to corporate responsibility strategies as well as social and philanthropic investments as attributes that drive brand loyalty (Kim and Chan-Olmsted, 2005). However, brands are rather much like consumers' own evolving attitudes and behaviours: their actual value is perceived to be situated in the minds and hearts of consumers. Brand attitudes derive from the perceived value of relationships between the organisation and their publics, or from perception of product or service quality (Kim and Chan-Olmsted, 2005).Consumer decision-making processes are themselves subject to marketing research; studies show brand salience influence decision making and attitudes, which can sustain businesses even in unstable economic periods (Aaker, 2011: 309-10).

Jeffrey Rayport (2013: 78), however, theorises that the competitive advantage from advertising, branding and PR in the media-saturated consumer world is largely temporal; marketing effectiveness must factor in human experience. This essentially assumes that creative and tactical approaches of marketing must be positioned within interventional spheres that consumers will welcome as part of their own experiences (Rayport, 2013: 84). The four spheres are discussed next, and their implications for marketing communication will be presented in the further section.

\subsection{Public Sphere}

According to Rayport (2013: 79) the public sphere is where people move from one place or activity to another, and this takes place in both physical and virtual realms.Traditional brand communication activities uses the public sphere to address practical consumption functions, directly but not intrusively accessing people's daily lives as 'branded interventions', while at the same time, builds organisational goodwill and are culturally relevant as they are found "in the midst of everyday life" (Rayport, 2013: 80). Advertising designed to be experienced in the public sphere drives awareness, trial and buying intention, and this form of commercial intervention are designed for "encounters in open spaces'.

\subsection{Social Sphere}

The social sphere of consumer engagement means activities and tactics that are relevant to customers' social needs, allowing these ideas to penetrate the ways they interact, seep into their relationships (perhaps even strengthening them), and provide a frame of solutions or answers to people's social needs (Rayport, 2013: 80-81). Leiss et al (2005: 4) took a broad view about the value of social communication in the marketplace, noting that people communicate their "sense of identity, values, intentions and aesthetics expressions" in personal life spaces: their talk, thoughts and acts; but this form of communication is also material, found in specific patterns of ownership, display, preference, and the use of goods and services that helps articulate connection with similar others.

\subsection{Tribal Sphere}

Rayport (2013: 81) defines this as spaces of group identification, expression and affiliation, where individuals feel connection and empowerment within groups through the use of symbolic markers of their social status. Luxury goods are noted for their ability to attract elite users - the so-called 'brand ambassadors' - but this practice is applied to mass marketing as well. As an aspect of cultural marketing, the tribal concept targets a faithful 'tribe' of followers who want to be seen (and acknowledged) by others for seeking goods with assured quality, value and positive attributes.

\subsection{Psychological Sphere}

The psychological sphere is another domain of human experience which helps brands sustains a "rewarding presence" in several ways (Rayport, 2013: 78). Marketers must consider the tangible benefits of psychological elements in articulating consumers' emotions and needs, as these are consciously or unconsciously associated with actions: in guiding decisions and behaviours and promoting certain moods. Brand taglines, service mottos and corporate slogans are psychological instances which extents consumers' own desires - designed to inspire thought, vision and aspiration.Consumers, argue Rayport (2013: 84), can undermine how brands engage with them, if they perceive the marketing as "invasive and exploitative". Researching attitudinal and behavioural responses, knowing how to "get permission" from the target markets, along with cultural message adaptation, are crucial for global companies to effectively serve consumers in cultural differentiated retail environments. The next section overviews the method of research and analysis in this paper.

\section{Method of RESEARCH}

To understand the effectiveness of integrating human experiences in consumers' specific cultural context, the overarching assumption taken by Rayport (2013: 79) is that brand communication 
practices embed the brand philosophy, values and messages into the four domains of human experience, namely, public, social, tribal and psychological spheres. A case study of Swedish furniture retail brand IKEA's branding, design philosophy and marketing tactics is the basis for examining the application of each sphere of human experiences in consumers' decision-making. This method is aligned to field studies in marketing concept (Leiss, Klein, Jhally, Botterill, 2005: 8-9), which argues that factors such as integrated marketing, brand communication and customer needs orientation contribute heavily to the rise of globally successful businesses, whereby persuasive strategies are employed purposefully to improve market foresight and to know customers' needs "even better than customers themselves" (Kotler et al, 2005: 16-17). Marketing efficiently to target consumers implies integrating the classic four P's of marketing, namely product, price, promotion and place. In the strategic application of Rayport's conceptual frame, it is also critical to discover specific needs adapted to cultures, and designing the business concept to communicate goods' availability and desirability to the segments (Leiss et al, 2005: 8).

\subsection{Case Study: IKEA's Brand Culture in Shaping Consumer Lifestyle Experiences}

IKEA is the world's largest furniture retailer, founded by Ingvar Kamprad, who articulated his småländsk ('no excess' vision) for a business model that promotes functional design as the philosophy and basis for retailing success (Kotler et al, 2005: 546), leading to the growth of over 350 stores around the world since 1960s, selling a wide range of home furnishing products bearing the five hallmarks of democratic design ("design for everyone") including form, function, quality, sustainability and low prices (IKEA Singapore, n.d.). IKEA displays products in room-like settings rather than putting goods in homogeneous showrooms, besides using a self-service model based on display of information on price tags (e.g. detailed measurements), instead of providing additional staff for sales assistance.

Designing the experience behind customer satisfaction start with acknowledging cultural differences, culture differences not only encompass language, but also the specific behaviours, preferences and tastes of consumers, leading marketers to opt for brand adaptation, particularly for the eclectic Asian markets (Burt and Johansson, 2008: 3). For IKEA, this important attribute is seen in their strategic branding approaches. Global cultural marketing call for contextualised brand messages that characterises a strong organisational identity throughout the world (Aaker, 2011: 200), IKEA's standardisation of retail management has led to global operational efficiency, yet undoubtedly, its deliberate and continual emphasis on environmental sustainability initiatives has enabled IKEA to achieve a sustainable competitive edge (IKEA People \& Planet, n.d.).Crilly (2011: 2) studied the designers' role in creating 'persuasion knowledge': creative design of products and systems that promote efficient energy and resource usage while encouraging responsible recycling and disposal. The following section discusses how IKEA manages its global branding through the design of merchandise, selling environment, and advertising (Burt and Johansson, 2008), and relates these activities to Rayport (2013)'s conceptual frame of human experiences.

\section{FINDINGS AND DISCUSSION}

Visibility is the marketers' weapon in attempting to focus customer experiences resourcefully. In the context of postmodern society, this factor has been linked to the blurring of cultural practices globally, arising from the rise of the middle-class and the growth of mass consumer societies that has shifted from previously rigid socio-economic class stratification to more fluid class-cultural structures that interconnects consumers' identities and lifestyles (Rosenberg, 2005). To be identified as consumers of particular brands, people are driven by the desire to individualise their spaces, status and lifestyles (Rosenberg, 2005).

\subsection{IKEA Concept: Culture Marketing in Motion}

IKEA uses a visible public sphere of persuasion through constructing a consistently modernist image of a high-street brand which offers self-assembled furniture in its aim to shift historical class associations of elitist European culture. IKEA's sharp brand marketing and advertising tactics directs the consumer to its no-nonsense public image under the banner concept of 'democratic design'. With customised store designs and various facilities such delis, child-minding services and extended hours, the innovative approach of making "handsome, cheap everyday articles available to many people at a price they can afford" (Kamprad and Torekull, 1999: 153) suggests that access to public sphere has 
only become the recent domain of a wider socioeconomic sector, and design has enlarged the trajectory of cultural appreciation that once was reserved for the higher strata.

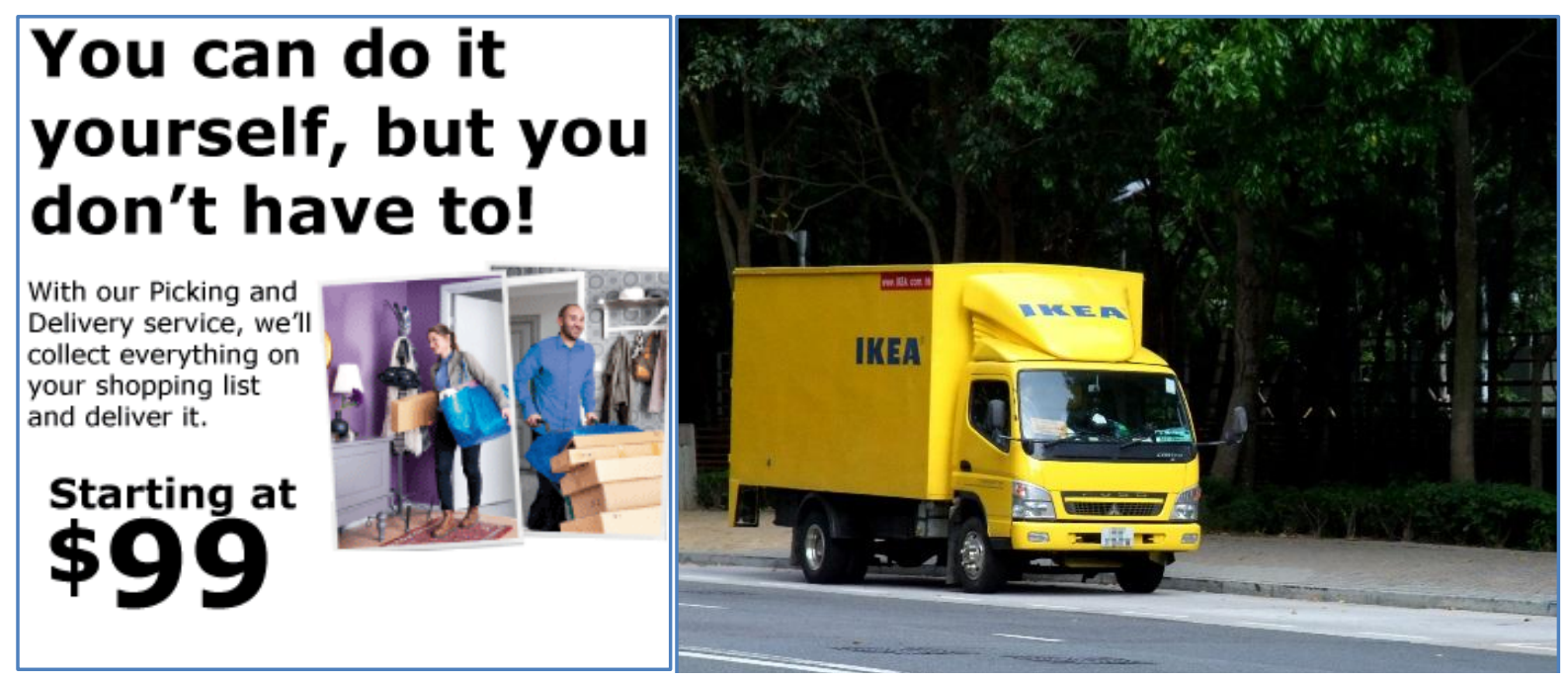

Figure1. IKEA New York Delivery Service

Figure2. IKEA's Yellow and Blue Delivery Truck

Self-assembly is IKEA's USP, and it operates on a centralised, global sourcing and supply chain model to enable mass-manufactured furniture to be produced and sold at low costs through stores located in suburban rather than city centres (Burt and Johansson, 2008: 25; Kotler et al, 2005: 868). Self-service in IKEA stores is another differentiation. Customers are encouraged to self-transport and self-assemble to eliminate transport costs, thus improving value for the middle-income segment, willing to self-transport and self-assemble furniture. For large items, home delivery services (Figure 1) are provided through its local outlets around the world via its iconic yellow and blue trucks (Figure 2) that have helped situate the Swedish brand in the public sphere (Rayport, 2013: 79).

\subsection{IKEA Brand and Marketing Catalogue: A Tribal Status Marker}

In analysing cultural marketing philosophy, it becomes obvious that what Elen Lewis (2008: 118) terms the "Swedish provenance" - a set of sparse cultural values (e.g. minimalistic interior design, simplicity of material forms) - lies at the heart of the Swedish ideology of modern creativity and good sense. Strategically, the position occupied by the IKEA brand derives from classical Scandinavian folk heritage, inherently reinforced and applied through its $19^{\text {th }}$-century inspired designs (IKEA Swedish Heritage, n.d.).

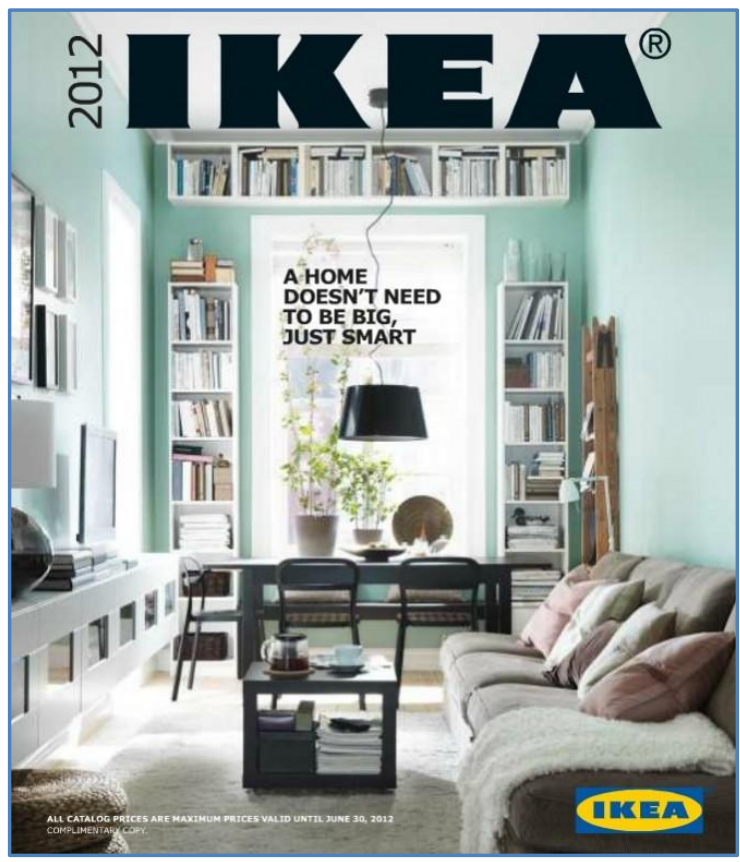

Figure3. Front Cover of IKEA's 2012 Catalogue

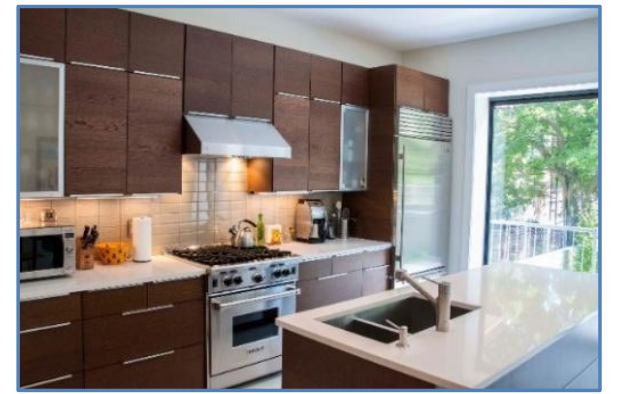

Figure4. Real Photography of IKEA Kitchen

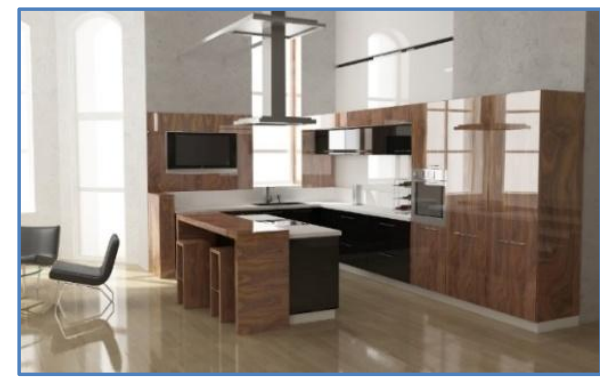

Figure5. IKEA's 3D Kitchen (Hansegard, 2012) 
To market sturdy yet stylish home and industrial designs, IKEA promulgates an utopian sense of community among its dominant cohort of urban customers, consciously avoiding the kitsch nostalgia of archaic cultural branding, yet embracing the egalitarian sensibility that lies behind the company's philosophy of "democratic design" (IKEA Democratic Design, n.d.), where minimalist designs combine with the opportunity for consumers "to invest themselves emotionally into mass-produced goods ... [forming] the elusive connectives that result in lasting loyalty" (Brown, Kozinets and Sherry, 2003: 21).

In contrast to typical furniture stores that classify products into categories, IKEA focuses on two factors: in-store display of furnishing in real settings and the iconic catalogue (Figure 3). The early 2000s were successful in attempts to reach audiences through custom magazines giving disinterested American readers ideas for home design and interior trends, while showcasing (Figure 4) store merchandise (Belch and Belch, 2003: 402-3). More recently, the US ad-mag trend has morphed into a monthly-updated lifestyle website (IKEA Family Live Magazine, n.d.), on top of approximately 100 million printed copies full-colour catalogues which reach 40 countries, and is a vital component of its marketing and promotion tactic. Catalogues, however, are expensive to produce and publish, and efforts to slim marketing costs has led the retailer to shift from previous real studio photography featuring actual furniture and interior settings, to 3D-designed catalogues (Figure 5) created with computer-generated digital graphics (Hansegard, 2012).

\subsection{IKEA Store Design: Using the Psychological Weapon}

Visualisation of customers' home needs within the layout of IKEA is achieved via a graphical, maze-like experience (Tozer, 2011). Alan Penn at University College of London created a succinct diagram which explains how IKEA's store design maximises customer engagement in the psychological sphere (Figure 6).

The maze-like store design allows for greater consumer choice and self-select, which suits urban, educated customers who are seeking fresh ideas for decoration and have had too much exposure to stores with over-categorisation of products. Returning to Rayport (2013), the four unique spheres to position often overlaps, yet if different marketing activities can be valuable instead of invasive, habit-forming instead of exploitative. IKEA's activities connect to the psychological shopping behaviour that reinforces

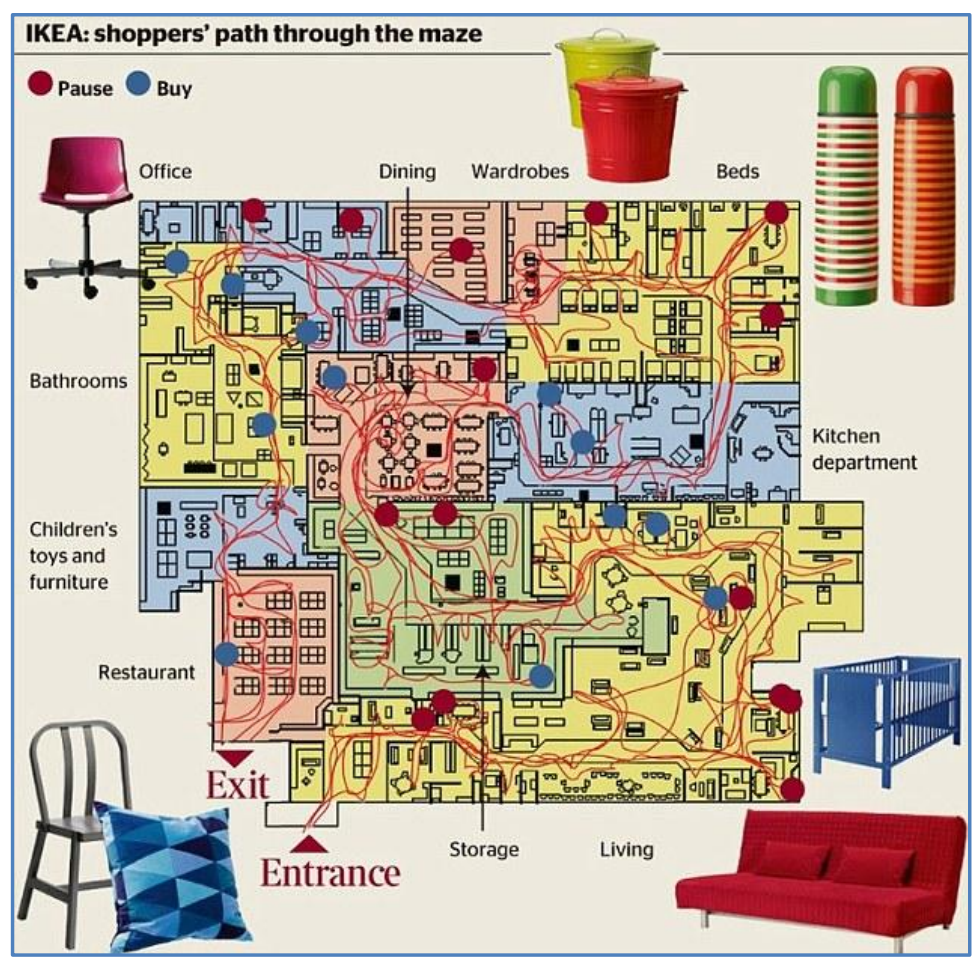

Figure6. Visitor route within the maze-like IKEA store (Penn, 2011) customers' intelligence as highly discerning of their choices.

\subsection{IKEA Advertising Symbolism: Where Social Media Meets Sofa}

IKEA's integration of packaging panache and stylish product design into its branding tactics has worked efficiently in most global territories, but not all markets appreciate its virtues. Established companies are just as vulnerable as smaller businesses to brand disasters as a result of costly mistakes. In the mid-1970s, when IKEA boldly forayed into Tokyo, the Japanese market had not adapted to the furniture self-assembly concept. From its lack of familiarity with self-assembly methods and small living spaces, Japanese customers perceived Brand IKEA as an aggressive European retailer but one that could not address their social needs. In 1986, IKEA decided to exit (Lane, 2007) after struggling to deal with strong local competitors such as MujirushiRyohin, better known as Muji (Capell, 2006; 
Wijers-Hasegawa, 2006). Market research and visits to Japanese homes were conducted to understand local perceptions and tastes towards packaging design (Jonsson, 2008; Wijers-Hasegawa, 2006), and as a result, IKEA re-opened twenty years later, with adaptations of furniture design that demonstrates closer understanding of the characteristics of Japanese homes and lifestyle behaviours of the locals. Humbled by its initial inability to dent the "very demanding" Japanese market, IKEA finally acknowledged the importance of local cultural experiences that impact lifestyle and consumer behaviour (2006). In responding, IKEA introduced charged home delivery and assembly services, offering low-price products and space-saving solutions such as storage box, sofa beds, two-seater sofa and etc. to suit the cramped Japanese lifestyle (Wijers-Hasegawa, 2006). Clearly, marketing crisis management taps into both the public and psychological spheres of brand management, for both global brands and small enterprises.

A recent yardstick of IKEA's success with advertising campaigns is in the way it resonates on the social dimension. In 2014, its catalogue advertising campaign, bookbook ${ }^{\mathrm{TM}}$ used a subverted form of technological innovation to play along the concept of consumers' digital lifestyle (Campaign Brief Asia, 2014; IKEA Singapore, 2014).

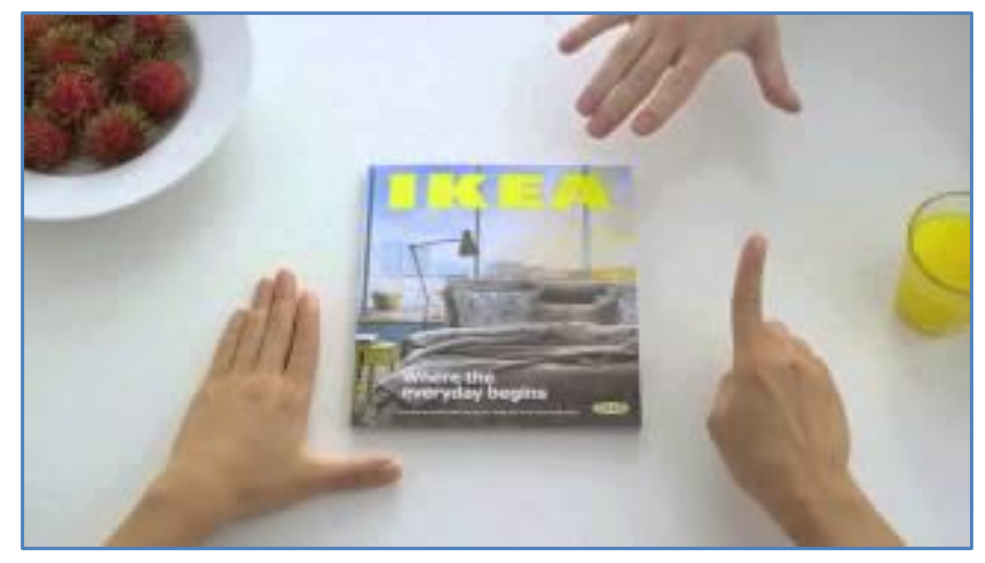

Figure7. IKEA bookbook ${ }^{\mathrm{TM}}$ campaign in 2014 by BBH Asia Pacific The tongue-in-cheek behavioural targeting tactic of bookbook ${ }^{\mathrm{TM}}$ was timed to catch tech-savvy Generation Y customers' attention, who in previous months had been flooded with repeated viral of the Apple iPhone 6 release touted on media spaces such as YouTube and through its Apple Experience campaign. The daring, selfreferential parody commercial brought IKEA to a new level of interactivity (Figure 7), and BBH Asia Pacific, the advertising agency was "pleasantly surprised by the fairly universal enjoyment of the [commercial]" (Marketing Interactive, 2014).

\section{RECOMMENDATIONS AND CONCLUSION}

This paper found Rayport's four spheres clearly operant in IKEA's marketing concept. The public sphere strategy is characterised by its use of do-it-yourself (DIY) culture, including self-transport and self-assemble of furniture. The tribal sphere strategy is presented through IKEA's magazine and catalogue publications, representing a material collection of people's collective fantasies and dreams of 'a perfect home'. The social sphere strategy is seen in IKEA's commercial advertising approaches, particularly those that have 'invaded' personal spaces through social media. Lastly, IKEA also shows a strong concern for the psychological strategy by encouraging customers to 'enter' its maze-like store design, and to provide attractive room-like settings for its merchandise.

Strategic marketing innovation drives a company to seek value-added interactions with customers in different cultural environments. Nevertheless, standardised operational practices often prove to be difficult for the management of certain markets, such as the case of self-checkout counters not working in IKEA stores in US (Fierce Retail, 2012). Global brands must therefore be informed by local concerns in order to adapt strategies for specific markets. Though integration and centralisation of management decisions has enabled IKEA to retain its brand essence (Burt and Johansson, 2008), today's markets demand and expect different activities suited to specific or unique lifestyle needs. Using the human experiences model to understand public, tribal, social and psychological spheres of consumers, large franchises and retail stores can deliver high value services, improve its pricing, promotion and selling environment, while broadening brand reach.

Newer forms of marketing practices use loyalty-based models of organisation-customer relationships to cultivate brand tribes (see, for example, Kozinets, 1999), global retailing chains could add weight to its branding tactics by ensuring minimally intrusive marketing communication and innovation approaches in their corporate and retail literature, store layout concept, products and services with distinct brand identity, communities on social networks, etc. Regardless of these practices, counter 
movements have emerged in recent years. For instance, in contrast with increasing global trade of identical commodities, Grose (2010) found the Internet to be a refreshing way to harness creative social capital through the process of crowdsourcing, where designers submit furniture design ideas which customers vote on before the product is considered viable for the market.

Effort and care to communicate the philosophy of self-expression through "design for the masses" is especially important, and must consistently capture audience's familiarity with the business concept, ensuring the characteristics of specific regions and cultures are adopted wisely in advertising and marketing communication tactics that acknowledge cultural sensitivities in their brand image. Evaluation through behavioural tracking, PR impressions, online feedback and store observation are necessary to produce critical improvements that enable companies to deliver return on investment on marketing and branding. Certainly, with the four spheres of human experiences being applied with equal salience, IKEA's ability to serve vastly different markets through the democratisation of good design and customised cultural marketing strategies can be sustained in years to come.

\section{REFERENCES}

Aaker, D. (2011) Building Strong Brands. London: Simon \& Schuster, Inc.

Belch, G.E. and Belch, M.A. (2003) Advertising and Promotion: An Integrated Marketing Communications Perspective. $6^{\text {th }}$ edn. London: McGraw-Hill Co.

Brown, S., Kozinets, R.V. and Sherry, J.F. Jr. (2003) Teaching Old Brands New Tricks: Retro Branding and the Revival of Brand Meaning.Journal of Marketing, 67(3), pp. 19-33.

Burt, S. and Johansson, U. (2008) IKEA's marketing strategies in China Sweden and the UK. [Conference Paper] Stockholm: The Nordic Retail and Wholesale Conference 2008.

Campaign Brief Asia (2014, September 3) IKEA invites you to experience the power of a book via campaign created by BBH Asia Pacific. Retrieved from http://www.campaignbriefasia.com/ 2014/09/ikea-invitesyou-to-experience.html

Capell, K. (2006, April 25) IKEA's New Plan for Japan.Bloomberg Business. Retrieved from http://www.bloomberg.com/bw/stories/2006-04-25/ikeas-new-plan-for-japan

Crilly, N. (2011) Do Users Know What Designers Are Up To? Product Experience and the Inference of Persuasive Intentions.International Journal of Design, 5(3): 1-15.

Fierce Retail IT (2012, August 15) IKEA Kills Self-Checkout in the U.S. for an Unusual Reason: It Was Too Secure and Therefore Too Slow. Retrieved from http://www.fierceretail.com/retailit/ story/ikea-kills-selfcheckout-in-the-u-s-for-an-unusual-reason-it-was-too-secure-and-therefore-too-slow

Grose, T.K. (2010, November 27) Sitting Pretty. Time. Retrieved from http://content.time.com/time/ magazine/article/0,9171,2031995,00.html

Hansegard, J. (2012, August 23) IKEA's New Catalogs: Less Pine, More Pixels. Wall Street Journal. Retrieved from http://www.wsj.com/articles/SB10000872396390444508504577595414031195148

IKEA Democratic Design (n.d.) Available at www.ikea.com/ms/en_SG/this-is-ikea/democraticdesign/index.html

IKEA Family Live Magazine (n.d.) Available at http://www.ikeafamilylivemagazine.com/us/en/

IKEA People \& Planet (n.d.) Available at http://www.ikea.com/ms/en_GB/about-the-ikea-group/people-andplanet/energy-and-resources/

IKEA Singapore (2014, September 3) Experience the power of a bookbook ${ }^{\mathrm{TM}}$. YouTube. Retrieved from https://www.youtube.com/watch?v=MOXQo7nURs0

IKEA Swedish Heritage (n.d.) Available at www.ikea.com/ms/en_MY/about_ikea/theikea_way/swedish heritage/index.html

Kamprad, I. and Torekull, B. (1999) Leading by Design: The IKEA Story. New York, N.Y.: Collins.

Kim, J. and Chan-Olmsted, S. M. (2005) Comparative effects of organisation-public relationships and productrelated attributes on brand attitude. Journal of Marketing Communications, 11(3): 145-170.

Kotler, P., Wong, V., Saunders, J. and Armstrong, G. (2005) Principles of Marketing. $4^{\text {th }}$ edn. Essex: Pearson Education Ltd.

Kozinets, R.V. (1999) E-Tribalized Marketing? The Strategic Implications of Virtual Communities of Consumption.European Management Journal, 17(3): 252-264.

Lane, G. (2007, September 17) Failed Business in Japan: A Study of How Different Companies Have Failed and Tips on How to Succeed, in the Japanese Market. Japan Inc. Retrieved from http://www.japaninc.com/mgz_sep-oct_2007_issue_failed-businesses 


\section{Stephen T.F. Poon}

Leiss, W., Kline, S., Jhally, S. and Botterill, J. (2005) Social Communication in Advertising: Consumption in the Mediated Marketplace. $3^{\text {rd }}$ edn. New York: Routledge.

Lewis, E. (2008) Great IKEA! A Brand for All the People. $2^{\text {nd }}$ edn. Singapore: Marshall Cavendish Ltd.

Los Angeles Times (2006, April 24) IKEA to Try Japanese Market Again. Retrieved from http://articles.latimes.com/2006/apr/24/business/fi-ikea24

Marketing Interactive (2014, September 12) Why IKEA Catalogue Campaign is So Successful. Retrieved from http://www.marketing-interactive.com/why-is-ikea-catalogue-campaign-so-successful/

Rayport, J.F. (2013) Advertising's New Medium: Human Experience. Harvard Business Review. March: 77-84.

Rosenberg, B.C. (2005) Scandinavian Dreams: DIY, Democratisation and IKEA. Transformations, 11. [Electronic Journal] Available at http://www.transformationsjournal.org/journal/issue11/article02.shtml

Tozer, J. (2011, January 24) Why Shoppers Find It So Hard to Escape from IKEA: Flatpack Furniture Stores are 'Designed Just like a Maze'. Daily Mail. Retrieved from http://www.dailymail.co.uk/femail/article1349831/Ikea-design-stores-mazes-stop-shoppers-leaving-end-buying-more.html\#ixzz3UDrcLkMF

Wijers-Hasegawa, Y. (2006, April 25) Sweden's IKEA Back in Japan After 20-year Hiatus. Japan Times. Retrieved from http://www.japantimes.co.jp/text/nb20060425a1.html

\section{IMAGES CREDIT}

Figure 1:IKEA New York Delivery Service. Available at http://www.ikea.com/us/en/store/ brooklyn /services

Figure 2:IKEA's yellow and blue delivery truck. Available at http://c8.alamy.com/comp/C8YW8N/ an-ikeahome-delivery-lorry-negotiates-narrow-roads-in-brighton-uk-C8YW8N.jpg

Figure 3: Front cover of IKEA's 2012 catalogue (US). Available at https://commdeco.wordpress.com/

Figure4: Real photography of IKEA Kitchen. Available at http://www.wsj.com/articles/ SB10000872396390444508504577595414031195148

Figure5: IKEA's 3D kitchen (Hansegard, 2012). Available at: http://www.wsj.com/articles/ SB10000872396390444508504577595414031195148

Figure 6: Visitor route within the maze-like IKEA store. Available at http://www.dailymail.co.uk/ femail/article-1349831/Ikea-design-stores-mazes-stop-shoppers-leaving-end-buyingmore.html\#ixzz3UDrcLkMF

Figure7: IKEA bookbook ${ }^{\mathrm{TM}}$ campaign in 2014 by BBH Asia Pacific. Available at http://www.marketinginteractive.com/watch-ikea-hilariously-position-print-catalogue-tech-device/ 